\title{
Outcome of stroke patients receiving different doses of recombinant tissue plasminogen activator
}

\author{
This article was published in the following Dove Press journal: \\ Drug Design, Development and Therapy \\ 18 May 2017 \\ Number of times this article has been viewed
}

\author{
Cheung-Ter Ong ${ }^{1,2}$ \\ Yi-Sin Wong ${ }^{3}$ \\ Chi-Shun $\mathrm{Wu}^{\prime}$ \\ Yu-Hsiang Su'
}

'Department of Neurology, Chia-Yi Christian Hospital, ${ }^{2}$ Department of Nursing, Chung Jen Junior College of Nursing, Health Science and Management, ${ }^{3}$ Department of Family Medicine, Chia-Yi Christian Hospital, Chia-Yi, Taiwan
Correspondence: Cheung-Ter Ong Department of Neurology,

Chia-Yi Christian Hospital, 539

Chung-Shao Road, Chia-Yi, Taiwan

Tel +8865276 504l

Email ctong98@yahoo.com.tw
Background and purpose: Intravenous recombinant tissue plasminogen activator (tPA) at a dose of $0.9 \mathrm{mg} / \mathrm{kg}$ body weight is associated with a high hemorrhagic transformation (HT) rate. Low-dose tPA $(0.6 \mathrm{mg} / \mathrm{kg})$ may have a lower hemorrhage rate but the mortality and disability rates at 90 days cannot be confirmed as non-inferior to standard-dose tPA. Whether the doses 0.7 and $0.8 \mathrm{mg} / \mathrm{kg}$ have better efficacy and safety needs further investigation. Therefore, this study is to compare the efficacy and safety of each dose of tPA $(0.6,0.7,0.8$, and $0.9 \mathrm{mg} / \mathrm{kg}$ body weight) and to investigate the factors affecting early neurological improvement (ENI) and early neurological deterioration (END).

Methods: For this observational study, data were obtained from 274 patients who received tPA thrombolytic therapy in Chia-Yi Christian Hospital stroke unit. The tPA dose was given at the discretion of each physician. The definition of ENI was a $>8$ point improvement (compared with baseline) at $24 \mathrm{~h}$ following thrombolytic therapy or an improvement in the National Institutes of Health Stroke Score (NIHSS) to 0 or 1 toward the end of tPA infusion. The definition of END was a $>4$ point increase in NIHSS (compared with baseline) within $24 \mathrm{~h}$ of $\mathrm{PAA}$ infusion. The primary objective was to investigate whether 0.7 and $0.8 \mathrm{mg} / \mathrm{kg}$ of tPA have higher ENI rate, lower END rate, and better outcome at 6 months. Poor outcome was defined as having a modified Rankin Scale of 3 to 6 (range, 0 [no symptoms] to 6 [death]). The secondary objective was to investigate whether low-dose tPA has a lower risk of intracerebral HT than that with standard-dose tPA. We also investigated the factors affecting ENI, END, HT, and 6-month outcome.

Results: A total of 274 patients were included during the study period, of whom 260 were followed up for $>6$ months. There was a trend for the HT rate to increase as the dose increased $(P=0.02)$. The symptomatic HT rate was not significantly different among the low-dose and standard-dose groups. The ENI and END $(P=0.52)$ were not significantly different among the four dosage groups. The clinical functional outcome at 6 months after stroke onset was poorer in the standard-dose group $(P=0.02)$. Stroke severity $(P<0.01)$, stroke type $(P=0.03)$, and diabetes mellitus $(P=0.04)$ affected the functional outcome at 6 months.

Conclusion: Among the 274 patients receiving tPA thrombolytic therapy, the HT rate increased as dose increased. The symptomatic HT, ENI and END rates were not significantly different among the low-dose $(0.6,0.7$, and $0.8 \mathrm{mg} / \mathrm{kg})$ and standard-dose groups. Stroke severity (NIHSS >12), stroke type (cardioembolism and large artery atherosclerosis) and diabetes mellitus were associated with poor outcome at 6 months.

Keywords: stroke, thrombolytic therapy, outcome, neurological deterioration, tissue plasminogen activator, thrombolysis

\section{Introduction}

Intravenous tissue plasminogen activator (tPA) was approved for the treatment of patients with acute ischemic stroke within $3 \mathrm{~h}$ of onset by the US Food and Drug Administration in 1996 and is still a standard treatment for patients with ischemic stroke. ${ }^{1-3}$

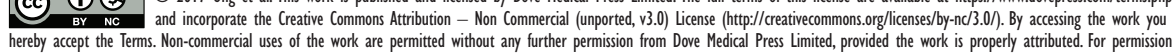
for commercial use of this work, please see paragraphs 4.2 and 5 of our Terms (https://www.dovepress.com/terms.php). 
Recently, the extended time window of thrombolysis to $4.5 \mathrm{~h}$ has been widely accepted in clinical practice. ${ }^{4,5}$ Because of a higher symptomatic hemorrhagic transformation ( $\mathrm{SHT}$ ) rate in patients who received thrombolytic therapy, ${ }^{1,6,7}$ a lower dose of tPA for ischemic stroke patients was suggested.$^{8}$ Based on the J-ACT study that reported that IV low-dose recombinant tPA $(0.6 \mathrm{mg} / \mathrm{kg})$ could offer both clinical efficacy and safety as a standard dose, ${ }^{9}$ the Japanese drug safety authority has approved the use of tPA $0.6 \mathrm{mg} / \mathrm{kg}$ for patients with ischemic stroke. Some studies have investigated the use of low dose (IV recombinant tPA $0.6 \mathrm{mg} / \mathrm{kg}$ ) for patients with ischemic stroke within $4.5 \mathrm{~h}$ of stroke onset and found the low dose to be as effective as the standard dose. ${ }^{10}$ Other studies found the standard dose to be better than the low dose in terms of functional outcome, and there was no difference in the hemorrhage rate. ${ }^{3,11}$ A study in Taiwan found that in comparison with the standard dose, patients who were treated with a low dose $(0.55-0.84 \mathrm{mg} / \mathrm{kg})$ had a lower hemorrhagic rate, lower mortality, and better functional outcome, especially in patients older than 70 years. ${ }^{7}$ In contrast to the study by Chao et al, a study in China found that in comparison with different low-dose tPA regimens, the standard dose had a better functional outcome, and the hemorrhagic rate was not different. ${ }^{3}$ An international study (the ENCHANTED study) showed that the sHT rate was significantly lower in patients treated with low-dose tPA, and both the mortality rate and functional outcome at 90 days were not significantly different between the low-dose and standarddose groups. ${ }^{12}$ Because the results regarding the efficacy and safety of low-dose tPA are inconsistent, a well-controlled study about the efficacy and dose of tPA is necessary. The early neurological improvement (ENI) rate is believed to be related to the restoration of blood flow in the occluded artery. ${ }^{13,14}$ As the thrombolytic effect of tPA lasts for only $3.5 \mathrm{~h},{ }^{15}$ the response to thrombolysis is best evaluated after the first $24 \mathrm{~h}$. Whether the doses 0.7 and $0.8 \mathrm{mg} / \mathrm{kg}$ have better efficacy and safety needs further investigation. Therefore, we performed a singlecenter study in the Chia-Yi Christian Hospital stroke unit. The primary objective was to investigate ENI, early neurological deterioration (END), and clinical outcome at both discharge and 6 months in patients administered each dose of tPA. The secondary objective was to investigate the relationship between the risk of intracerebral hemorrhagic transformation (HT) and dose of tPA infusion. We also investigated the factors affecting ENI, END, HT, and 6-month outcome.

\section{Methods}

In this retrospective observational study, all data were drawn from the stroke registry database of a teaching hospital in central Taiwan. We have been regularly using tPA for patients with acute stroke who are eligible for thrombolytic therapy since January 2007. According to the stroke management guidelines in Taiwan, tPA $\leq 0.9 \mathrm{mg} / \mathrm{kg}$ appears to be appropriate for ischemic stroke patients, and patients aged $>80$ years should not be given thrombolytic therapy. ${ }^{16}$ A neurologist was consulted when patients presented to the emergency department with acute ischemic stroke within $3 \mathrm{~h}$ of stroke onset without contraindications to thrombolytic therapy. On the basis of the aforementioned guidelines, all the patients in whom thrombolytic therapy was feasible were allocated to receive one of the doses $(0.6$ to $0.9 \mathrm{mg} / \mathrm{kg})$ at the discretion of each physician. Factors that may influence both tPA dose and treatment regimen were as follows: 1) Doctor experience: if the doctor had repeated experiences of patients having ( $\mathrm{sHT}$ ) or dying after being given standard-dose tPA, the physician may decide to use low dose. 2) Patient's condition: if a doctor thinks that the patient had a higher risk of HT, the physician may choose low-dose tPA. In patients aged $>80$ years without other contraindications who arrived within $3 \mathrm{~h}$ of stroke onset and requested thrombolytic treatment, tPA was given as well. Data from all the patients with stroke who received IV tPA treatment between January 2007 and December 2015 were included in the study. When the dosage of tPA was determined, IV $10 \%$ of the total dose was administered as a bolus, and the remainder as a continuous IV infusion for $>1 \mathrm{~h}$. Brain computed tomography (CT) was performed for every patient before IV tPA. Patients were followed up with CT or magnetic resonance imaging (MRI) for $24 \mathrm{~h}$ following tPA infusion. The National Institutes of Health Stroke Score (NIHSS) was used to assess stroke severity. An NIHSS-certified stroke team member at our facility performed the scoring and evaluation after every $6 \mathrm{~h}$ for the first $24 \mathrm{~h}$ and at discharge. No response was defined as an increase in NIHSS $\leq 4$ or a decrease in NIHSS $\leq 8$. An ENI was defined as an $>8$-point improvement (compared with baseline) after $24 \mathrm{~h}$ following thrombolytic therapy or an improvement in NIHSS to 0 or 1 toward the end of tPA infusion. Neurological improvement (NI) was defined as an >8-point improvement (compared with baseline) or an improvement in NIHSS to 0 or 1 at discharge. Neurological deterioration (ND) was defined as a $>4$-point increase in NIHSS (compared with baseline) at discharge. END was defined as a $>4$-point increase in NIHSS (compared with baseline) within $24 \mathrm{~h}$ of tPA infusion. All brain CT and MRI scans were evaluated by an independent radiologist who was blind to the dose of tPA. HT was defined as any sign of hemorrhage on the follow-up CT or MRI scans. The 

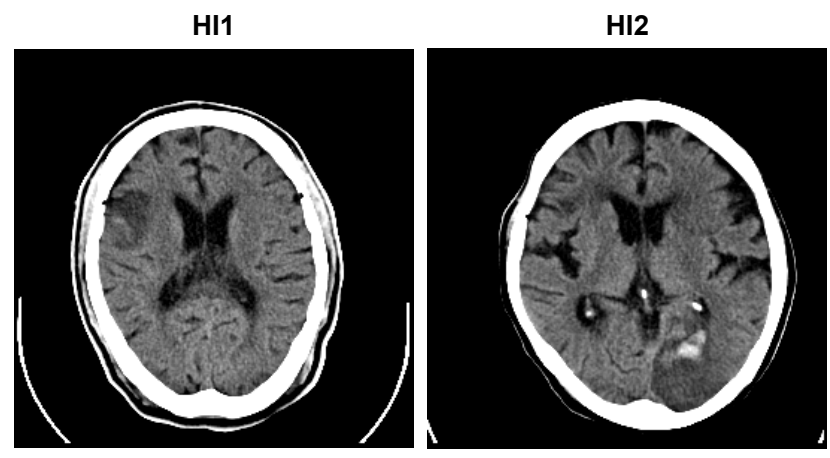

PH1
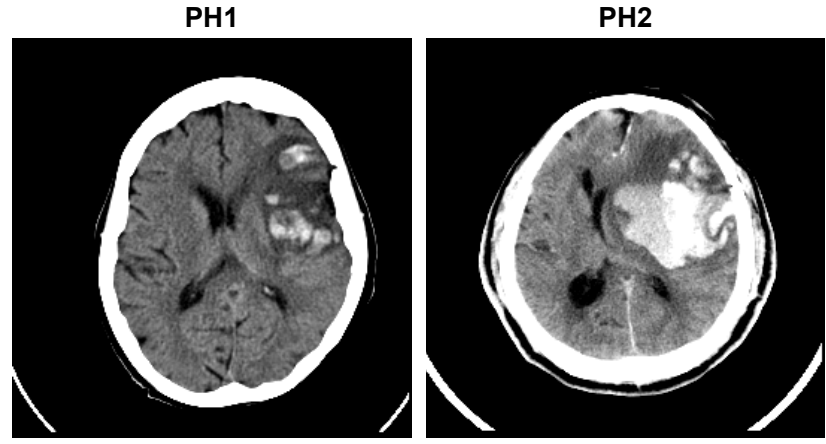

Figure I Subtype of hemorrhagic transformation HII (top left), HI2 (top right), PHI: (bottom left), PH2: (bottom right).

Abbreviations: HII, small petechiae subtype; HI2, more confluent petechiae subtype; $\mathrm{PHI}, \leq 30 \%$ of the infarcted area with mild space-occupying effect; $\mathrm{PH} 2$, $>30 \%$ of the infarcted area with significant space-occupying effect.

subtype of HT were HI1 (small petechiae), HI2 (more confluent petechiae), $\mathrm{PH} 1$ ( $\leq 30 \%$ of the infarcted area with mild space-occupying effect), $\mathrm{PH} 2$ ( $>30 \%$ of the infarcted area with significant space-occupying effect) (Figure 1). ${ }^{17}$ sHT was defined as blood clots in the brain observed during follow-up CT or MRI, with an increase in NIHSS by $\geq 4$ points. ${ }^{18}$ The modified Rankin Scale (mRS) was used to evaluate stroke severity and functional outcomes. Good and poor outcomes were defined as $\mathrm{mRS} \leq 2$ and $\mathrm{mRS}>2$, respectively. This study was approved by the Ethics Committee of the Chia-Yi Christian Hospital (CYCH-IRB: 096022) and written informed consent was obtained from each patient or the legal representative.

\section{Statistical analysis}

Statistical significance of the differences between age groups was analyzed using the chi-square or Fisher's exact test for categorical variables and analysis of variance for continuous variables including blood pressure, and time from stroke onset to tPA infusion (tPA time); and Kruskal-Wallis test for NIHSS. Multiple logistic regression analysis was used to identify risk factors for HT, ENI, and clinical outcome. A $P$-value $<0.05$ was considered to indicate statistical significance. The analyses were performed using SPSS software, version 21.0 of the SPSS system for Windows (Version 21.0; IBM Corporation, Somers, NY, USA).

\section{Results}

From January 2007 to December 2015, a total of 274 patients received IV tPA for acute ischemic stroke within $3 \mathrm{~h}$ of stroke onset in our hospital. Being a single-center study with a relatively small number of patients receiving thrombolysis, the dose of tPA was given at the discretion of the attending physician. Of the 274 patients included in the current study, there were 71 patients in the $0.6 \mathrm{mg} / \mathrm{kg}$ group, $59 \mathrm{in}$ the $0.7 \mathrm{mg} / \mathrm{kg}$ group, 88 in the $0.8 \mathrm{mg} / \mathrm{kg}$ group, and 56 in the $0.9 \mathrm{mg} / \mathrm{kg}$ group. A bolus of $10 \%$ of the total tPA dose was given for 1-2 min, and the remaining dose was given within $60 \mathrm{~min}$. The baseline characteristics of the patients, including sex, hypertension, atrial fibrillation, heart disease, smoking, lipidemia, stroke severity, time of tPA infusion, blood pressure, and stroke subtype, were not significantly different among the four groups except for age (Table 1). Age was slightly higher in patients who received $0.6 \mathrm{mg} / \mathrm{kg}$. Of the 274 patients, 260 were followed up for more than 6 months, and 14 lost to follow-up. There were 63 patients in the $0.6 \mathrm{mg} / \mathrm{kg}$ group, $57 \mathrm{in}$ the $0.7 \mathrm{mg} / \mathrm{kg}$ group, 85 in the $0.8 \mathrm{mg} / \mathrm{kg}$ group, and 55 in the $0.9 \mathrm{mg} / \mathrm{kg}$ group. In the $24 \mathrm{~h}$ after thrombolytic therapy, ENI was found in $31 \%(22 / 71)$ of patients who received $0.6 \mathrm{mg} / \mathrm{kg}, 35.6 \%(21 / 59)$ in the $0.7 \mathrm{mg} / \mathrm{kg}$ group, $36.4 \%(32 / 88)$ in the $0.8 \mathrm{mg} / \mathrm{kg}$ group, and $25.0 \%(14 / 56)$ in the $0.9 \mathrm{mg} / \mathrm{kg}$ group. No response rates were $64.8 \%$ (46/71) in the $0.6 \mathrm{mg} / \mathrm{kg}$ group, $55.9 \%$ (33/59) in the $0.7 \mathrm{mg} / \mathrm{kg}$ group, $56.8 \%(50 / 88)$ in the $0.8 \mathrm{mg} / \mathrm{kg}$ group, and $62.5 \%(35 / 56)$ in the $0.9 \mathrm{mg} / \mathrm{kg}$ group. The END rates were $4.2 \%(3 / 71)$ in the $0.6 \mathrm{mg} / \mathrm{kg}$ group, $8.5 \%(5 / 59)$ in the $0.7 \mathrm{mg} / \mathrm{kg}$ group, $6.8 \%(6 / 88)$ in the $0.8 \mathrm{mg} / \mathrm{kg}$ group, and $12.5 \%(7 / 56)$ in the $0.9 \mathrm{mg} / \mathrm{kg}$ group. In the $24 \mathrm{~h}$ after thrombolysis, both the ENI and ND rates were not significantly different between the groups $(P=0.52)$. The HT rate was highest in the $0.9 \mathrm{mg} / \mathrm{kg}$ group at $21.4 \%(12 / 56)$ followed by $5.6 \%$ $(4 / 71)$ in the $0.6 \mathrm{mg} / \mathrm{kg}$ group, $8.5 \%(5 / 59)$ in the $0.7 \mathrm{mg} / \mathrm{kg}$ group and $9.1 \%(8 / 88)$ in the $0.8 \mathrm{mg} / \mathrm{kg}$ group (Table 2). In comparison with the $0.6 \mathrm{mg} / \mathrm{kg}$ group, the odds ratios of HT were 1.55 in the $0.7 \mathrm{mg} / \mathrm{kg}$ group, $1.67 \mathrm{in} 0.8 \mathrm{mg} / \mathrm{kg}$ group, and $3.59 \mathrm{in} 0.9 \mathrm{mg} / \mathrm{kg}$ group $(P=0.02)$. There was a tendency for the HT rate to increase as the dose increased (trend for the hemorrhage rate $<0.01$ ) (Figure 2). The tendency of HT also increased as stroke severity increased. In comparison with the NIHSS 6-12 group, the odds ratios of hemorrhage were 1.90 in the NIHSS 13-20 group and 4.39 in the NIHSS 21-26 group $(P<0.01)$. The factors associated with HT were stroke 
Table I Characteristics of patients at baseline

\begin{tabular}{|c|c|c|c|c|c|}
\hline \multirow[t]{2}{*}{ Variables } & \multicolumn{4}{|l|}{ tPA } & \multirow[t]{2}{*}{$P$-value } \\
\hline & $0.6 \mathrm{mg}(\mathrm{N}=7 \mathrm{I})$ & $0.7 \mathrm{mg}(\mathrm{N}=59)$ & $0.8 \mathrm{mg}(\mathrm{N}=88)$ & $0.9 \mathrm{mg}(\mathrm{N}=56)$ & \\
\hline $\operatorname{Sex}(M), n$ & 31 & 38 & 55 & 34 & $0.05^{a}$ \\
\hline Age (years), mean $\pm S D$ & $71.8 \pm 10.6$ & $65.3 \pm 13.5$ & $62.2 \pm 12.9$ & $66.5 \pm 11.6$ & $0.0 \mathrm{I}^{\mathrm{b}}$ \\
\hline HTN, n & 57 & 43 & 67 & 43 & $0.70^{\mathrm{a}}$ \\
\hline DM, n & 30 & 18 & 21 & 24 & $0.57^{\mathrm{a}}$ \\
\hline $\mathrm{AF}, \mathrm{n}$ & 27 & 17 & 25 & 22 & $0.92^{\mathrm{a}}$ \\
\hline Heart disease, $n$ & 38 & 21 & 38 & 28 & $0.88^{a}$ \\
\hline Smoking, $\mathrm{n}$ & 24 & 29 & 41 & 24 & $0.29^{a}$ \\
\hline Lipidemia, n & 42 & 29 & 51 & 30 & $0.77^{\mathrm{a}}$ \\
\hline NIHSS, mean \pm SD & $14.9 \pm 7.2$ & $13.8 \pm 5.7$ & $13.1 \pm 5.9$ & $14.9 \pm 6.3$ & $0.24^{c}$ \\
\hline tPA time $(\min )$, mean $\pm S D$ & 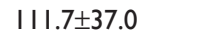 & $120.1 \pm 36.7$ & $113.6 \pm 44.2$ & $122.1 \pm 45.5$ & $0.4 I^{b}$ \\
\hline \multicolumn{6}{|l|}{ Blood pressure } \\
\hline Systolic $\mathrm{mmHg}$, mean $\pm \mathrm{SD}$ & $159.9 \pm 28.8$ & $160.7 \pm 28.9$ & $154.3 \pm 29.5$ & $155.8 \pm 27.8$ & $0.46^{b}$ \\
\hline Diastolic $\mathrm{mmHg}$, mean $\pm \mathrm{SD}$ & $90.1 \pm 17.6$ & $90.5 \pm 17.4$ & $90.4 \pm 17.8$ & $92.9 \pm 16.3$ & $0.80^{\mathrm{b}}$ \\
\hline \multicolumn{6}{|l|}{ Stroke type } \\
\hline Large artery, n (\%) & $20(28.2)$ & $18(30.5)$ & $21(23.9)$ & $21(37.5)$ & $0.03^{\mathrm{a}}$ \\
\hline Small vessel , n (\%) & $5(7.0)$ & $7(11.9)$ & I5 (I7.0) & $3(5.4)$ & \\
\hline Cardioembolism, n (\%) & 17 (23.9) & $18(30.5)$ & $24(27.3)$ & $23(4 I .0)$ & \\
\hline Undetermined, n (\%) & $29(40.9)$ & $16(27.1)$ & $28(3 \mid .8)$ & $9(16.1)$ & \\
\hline LOS (days), mean \pm SD $(95 \% \mathrm{Cl})$ & $10.4 \pm 8.8(9.5-13)$ & $9.3 \pm 7.3(6.8-10.5)$ & $10.2 \pm 8.4(8.3-11.9)$ & $13.5 \pm 10.9(10.6-11.6)$ & $0.06^{c}$ \\
\hline
\end{tabular}

Notes: ${ }^{\mathrm{C} C h i}$-square test; ${ }^{\mathrm{B} A N O V A}$ test; ${ }^{\mathrm{c} K r u s k a l-W a l l i s ~ t e s t . ~}$

Abbreviations: AF, atrial fibrillation; ANOVA, analysis of variance; $\mathrm{Cl}$, confidence interval; DM, diabetes mellitus; HTN, hypertension; LOS, length of stay; NIHSS, National Institutes of Health Stroke Score; SD, standard deviation; tPA, tissue plasminogen activator.

severity and tPA dose $(0.9 \mathrm{mg} / \mathrm{kg}$ ) (Table 3$)$. The HT rates were $22.0 \%$ (18/82) in cardioembolism, 5.0\% (4/80) in large artery atherosclerosis, 0 in small vessel occlusion, and $9.8 \%$ $(8 / 82)$ in patients with an undetermined cause. The subtypes of HT were HI1 in six, HI2 in eight, $\mathrm{PH} 1$ in nine and $\mathrm{PH} 2$ in six patients. In patients without HT, the ENI and END rates were not significantly different among the four groups. During patient discharge following stroke treatment, functional outcome was not significantly different among the four groups. There were $33.8 \%$ (24/71) of patients in the $0.6 \mathrm{mg} / \mathrm{kg}$ group, $40.7 \%$ (24/59), in the $0.7 \mathrm{mg} / \mathrm{kg}$ group, $48.9 \%$ (43/88) in the $0.8 \mathrm{mg} / \mathrm{kg}$ group, and $30.3 \%$ (17/56) in the $0.9 \mathrm{mg} / \mathrm{kg}$ group $(P=0.08)$ with good functional outcome (Figure 3). At 6 months after stroke onset, diabetes mellitus, stroke severity (NIHSS $>12$ ), and stroke type (cardioembolism and large artery atherosclerosis) were associated with poor outcome. Functional outcome was poorer in patients receiving the standard dose $(0.9 \mathrm{mg} / \mathrm{kg})$. In comparison with the $0.6 \mathrm{mg} / \mathrm{kg}$ group, the odds ratios of poor outcome were 1.67 in the $0.7 \mathrm{mg} / \mathrm{kg}$ group, $2.07 \mathrm{in}$ the $0.8 \mathrm{mg} / \mathrm{kg}$ group, and 2.97 in the $0.9 \mathrm{mg} / \mathrm{kg}$ group $(P=0.02)$ (Table 4$)$. Good functional outcome was observed in $50.8 \%(32 / 63)$ of the patients in the $0.6 \mathrm{mg} / \mathrm{kg}$ group, $56.1 \%$ (32/57) in the $0.7 \mathrm{mg} / \mathrm{kg}$ group, $64.7 \%(55 / 85)$ in the $0.8 \mathrm{mg} / \mathrm{kg}$ group, and $38.2 \%(21 / 55)$

Table 2 Primary and secondary outcomes at $24 \mathrm{~h}$ and discharge

\begin{tabular}{|c|c|c|c|c|c|}
\hline \multirow[t]{2}{*}{ Variables } & \multicolumn{4}{|l|}{ tPA } & \multirow[t]{2}{*}{$P$-value $\left(\chi^{2}\right)$} \\
\hline & $0.6 \mathrm{mg} / \mathrm{kg}(\mathrm{N}=7 \mathrm{I})$ & $0.7 \mathrm{mg} / \mathrm{kg}(\mathrm{N}=59)$ & $0.8 \mathrm{mg} / \mathrm{kg}(\mathrm{N}=88)$ & $0.9 \mathrm{mg} / \mathrm{kg}(\mathrm{N}=56)$ & \\
\hline \multicolumn{6}{|l|}{ Response at $24 \mathrm{~h}$} \\
\hline No & $46(64.8)$ & $33(55.9)$ & $50(56.8)$ & $35(62.5)$ & 0.52 \\
\hline ENI & $22(31.0)$ & $21(35.6)$ & $32(36.4)$ & $14(25)$ & \\
\hline END & $3(4.2)$ & $5(8.5)$ & $6(6.8)$ & $7(12.5)$ & \\
\hline \multicolumn{6}{|c|}{ Response at discharge } \\
\hline No & $30(42.3)$ & $26(44.1)$ & $31(35.1)$ & $23(4 I . I)$ & 0.51 \\
\hline $\mathrm{NI}$ & 34 (47.9) & $26(44.1)$ & $49(55.7)$ & $23(4 I . I)$ & \\
\hline ND & $7(9.9)$ & $7(11.8)$ & $8(9.1)$ & $10(17.8)$ & \\
\hline Hemorrhagic & $4(5.6)$ & $5(8.5)$ & $8(9.1)$ & $12(21.4)$ & $0.02($ trend $<0.01)$ \\
\hline $\mathrm{SICH}$ & I (I.4) & $5(8.5)$ & I (I.I) & $3(5.4)$ & 0.07 \\
\hline Good outcome & $24(33.8)$ & $24(40.7)$ & $43(48.9)$ & $17(30.3)$ & 0.08 \\
\hline $6 \mathrm{~m}$ good outcome $\mathrm{e}^{\#}$ & $32 / 63(50.8)$ & $32 / 57(56.1)$ & $55 / 85(64.7)$ & $21 / 55(38.2)$ & 0.02 \\
\hline
\end{tabular}

Notes: Data shown as $\mathrm{n}(\%)$. "Modified ranking scale $\leq 2$ at 6 months.

Abbreviations: END, early neurological deterioration; ENI, early neurological improvement; ND, neurological deterioration; NI, neurological improvement; No, no neurological improvement and no neurological deterioration; $\mathrm{SICH}$, symptomatic hemorrhagic transformation. 


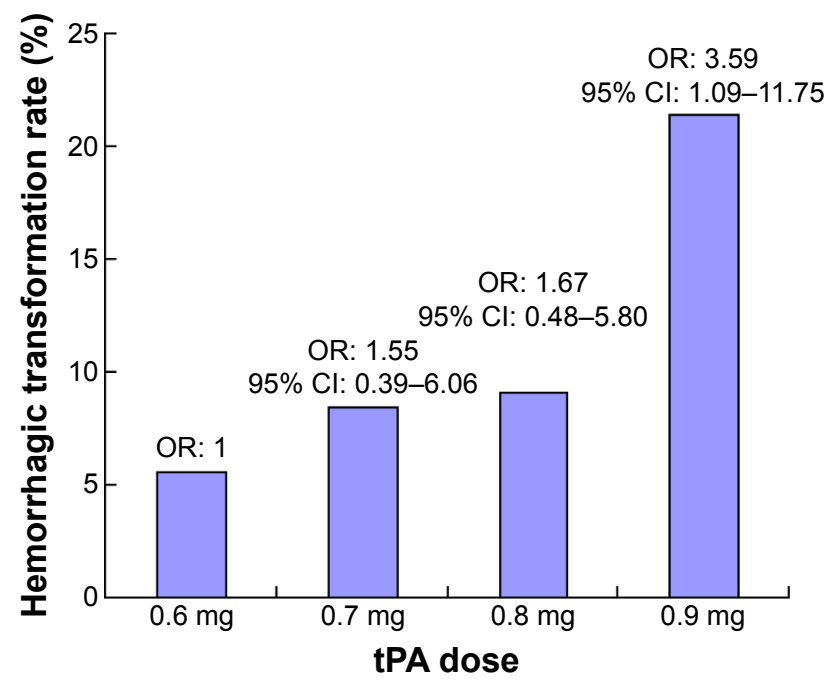

Figure 2 Hemorrhagic transformation rate at each dosage of tPA $(P=0.02)$. Note: tPA dose indicates the intravenous dose the patient received at $\mathrm{mg} / \mathrm{kg}$ of body weight.

Abbreviations: $\mathrm{Cl}$, confidence interval; OR, odds ratio; tPA, tissue plasminogen activator.

in the $0.9 \mathrm{mg} / \mathrm{kg}$ group (Figure 4). In comparison with the patients in the NIHSS 6-12 group, the odds ratios of poor outcome at 6 months were $3.7(P<0.01)$ in the NIHSS $13-20$ group and $7.8(P<0.01)$ in the NIHSS $20-26$ group.

\section{Discussion}

Our study has three important findings regarding the dosage of tPA infusion. First, the ENI and END rates were not significantly different among the four groups. Second, the HT rate increased as the TPA dose increased. Third, the functional outcome at 6 months after stroke onset was associated with stroke severity, stroke type, and diabetes mellitus. In the current study, the total HT rate was 10.6\% (29/274), which is compatible with those of previous studies ${ }^{6,19}$ that reported HT rates were between $9.1 \%$ and $10.6 \%$. However, in our patients who received $0.9 \mathrm{mg} / \mathrm{kg}$ tPA, the HT rate was $21.4 \%(12 / 56)$, which is twice that of previous studies. In our study, the HT rate in patients in the lower-dose group was between $5.6 \%$ and $9.1 \%$. Although this HT rate is lower than the rate reported in Japan, it is similar to the studies performed in Western countries with IV tPA $0.9 \mathrm{mg} / \mathrm{kg}$ in patients with ischemic stroke. ${ }^{20}$ Their HT rate was between $23.2 \%$ and $25.7 \% .^{8,10}$ Our study confirmed the findings of Mehta et al, who found that in comparison with Caucasian patients, the HT rate was higher in African-American and Asian patients. ${ }^{19}$ Our results show that the HT rate increased rapidly in patients who received $0.9 \mathrm{mg} / \mathrm{kg}$ IV tPA (Figure 2). Whether these results imply that $0.9 \mathrm{mg} / \mathrm{kg}$ is not the best

Table 3 Factors affect hemorrhagic transformation

\begin{tabular}{|c|c|c|c|c|c|}
\hline Variables & Patients $(\mathrm{N}=\mathbf{2 7 4})$ & OR $(95 \% \mathrm{CI})^{\mathrm{a}}$ & $P$-value ${ }^{a}$ & OR $(95 \% \mathrm{CI})^{\mathrm{b}}$ & $P$-value ${ }^{b}$ \\
\hline $\operatorname{Sex}(F)$ & $15 / 116(9.3 \%)$ & I.4I (0.66-3.02) & 0.37 & I.38 (0.43-4.44) & 0.58 \\
\hline \multicolumn{6}{|l|}{ Dose } \\
\hline $0.6 \mathrm{mg} / \mathrm{kg}$ & 5/7I (7.0\%) & I & & I & \\
\hline $0.7 \mathrm{mg} / \mathrm{kg}$ & $5 / 59(8.5 \%)$ & $2.73(0.96-9.00)$ & 0.06 & $2.65(0.90-7.78)$ & 0.07 \\
\hline $0.8 \mathrm{mg} / \mathrm{kg}$ & 8/88 (9.1\%) & 2.95 (1.04-7.18) & 0.04 & $3.21(0.94-10.9)$ & 0.06 \\
\hline $0.9 \mathrm{mg} / \mathrm{kg}$ & I2/56 (2I.4\%) & $3.60(1.19-10.9)$ & 0.02 & $3.78(1.12-12.7)$ & 0.03 \\
\hline Atrial fibrillation & |4/9| (I5.4\%) & $1.90(0.88-4.08)$ & 0.10 & 3.58 (0.09-1.04) & 0.05 \\
\hline Diabetes mellitus & $8 / 93(8.6 \%)$ & 0.68 (0.29-I.59) & 0.38 & $0.90(0.33-2.40)$ & 0.83 \\
\hline Hypertension & 25/210 (1 I.9\%) & $1.60(0.58-4.35)$ & 0.36 & I.36 (0.43-4.28) & 0.59 \\
\hline \multicolumn{6}{|l|}{ Stroke severity } \\
\hline NIHSS 6-I2 & $8 / 130$ (6.2\%) & I & & $\mathrm{I}$ & \\
\hline NIHSS I3-20 & I2/94 (I2.8\%) & I.7I (0.68-4.29) & 0.25 & 1.77 (0.60-5.15) & 0.29 \\
\hline NIHSS 2I-26 & $10 / 50$ (20.0\%) & $3.81(1.4 I-10.3)$ & 0.008 & $2.64(0.84-8.21)$ & 0.09 \\
\hline Smoking & I I/I I 8 (9.3\%) & $0.93(0.57-1.52)$ & 0.77 & I.0I (0.30-3.38) & 0.98 \\
\hline Alcohol & $\mathrm{I} / 28(3.6 \%)$ & $0.78(0.35-1.76)$ & 0.55 & $0.40(0.04-3.63)$ & $0.4 I$ \\
\hline Hyperlipidemia & I3/I52 (8.6\%) & I.24 (0.76-2.03) & 0.3 & $0.58(0.24-1.37)$ & 0.21 \\
\hline \multicolumn{6}{|l|}{ Stroke type } \\
\hline Cardioembolism & I8/82 (22.0\%) & I & & $\mathrm{I}$ & \\
\hline LAA & $4 / 80(5.0 \%)$ & $0.38(0.16-0.94)$ & 0.04 & $0.25(0.07-0.92)$ & 0.04 \\
\hline SMO & $0 / 30$ & NA & NA & & NA \\
\hline UN & 8/82 (9.8\%) & 2.05 (0.59-7.II) & 0.25 & $2.75(0.73-10.39)$ & 0.13 \\
\hline \multicolumn{6}{|l|}{ Age (years) } \\
\hline$\leq 50$ & $1 / 32$ & I & & I & \\
\hline $5 \mathrm{I}-70$ & $13 / 119$ & $1.22(0.56-2.66)$ & 0.62 & $0.85(0.34-2.12)$ & 0.72 \\
\hline$>70$ & $16 / 123$ & $4.64(0.59-36.4)$ & 0.14 & $2.18(0.24-198)$ & 0.48 \\
\hline
\end{tabular}

Notes: aMultiple logistic regression (univariate analysis); ${ }^{b}$ multiple logistic regression adjusted for age, sex, dose, atrial fibrillation, diabetes mellitus, hypertension, stroke severity, smoking, alcohol, hyperlipidemia, and stroke type.

Abbreviations: $\mathrm{Cl}$, confidence interval; LAA, large artery atherosclerosis; NA, not available; NIHSS, National Institutes of Health Stroke Score; OR, odds ratio; SMO, small vessel occlusion; UN, undetermined. 


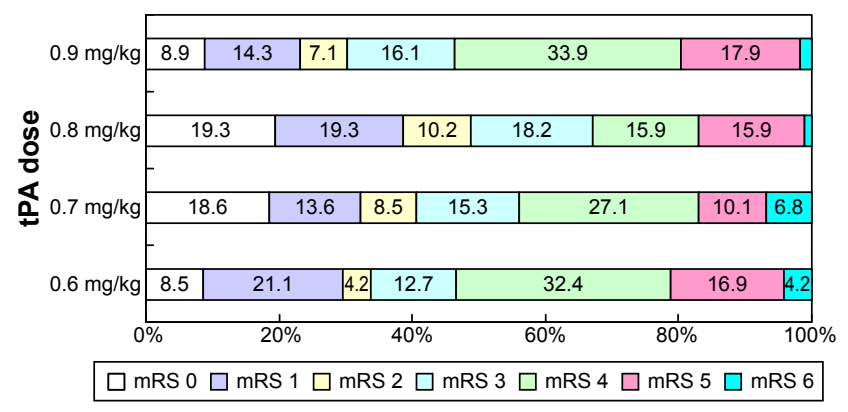

Figure 3 Functional outcomes at discharge according to mRS score.

Notes: The figure shows the distribution of scores on the mRS at discharge. Scores on the $\mathrm{mRS}$ range from 0 to 6 , with 0 indicating no symptoms, I - without clinical disability, 2 - mild disability, 3 - moderate disability, 4 - moderately severe disability, 5 - severe disability, and 6 - death.

Abbreviation: mRS, modified Rankin Scale.

choice of tPA for Taiwanese people is an unresolved issue that requires further investigation. This result is compatible with those of previous studies. ${ }^{3,21}$ Our results are also compatible with the results of the ENCHANTED study with respect to both HT rate and long-term outcome. The ENCHANTED study showed that the fatality rate and disability rate at 90 days was not significantly different between the low-dose and the standard-dose groups. That study also showed the sHT rate was significantly lower in the low-dose group than in the standard-dose group. ${ }^{12}$ Our result showed the sHT rate was not different between the low-dose and standard-dose groups and the clinical outcome at 6 months was poorer in the $0.9 \mathrm{mg} / \mathrm{kg}$ group. This difference may be related to the international level enrollment of the ENCHANTED study, which included $63 \%$ of Asians and $37 \%$ of non-Asians, whereas our study had a relatively small patient number. However, the results of our study showed a trend toward increase in the hemorrhage risk as the dose increased. The ENI rate is considered to be related to re-canalization of the occluded artery. ${ }^{13,14}$ The ENI rates were $32.5 \%$ (89/274) of the total 274 patients, $31.0 \%$ in the $0.6 \mathrm{mg} / \mathrm{kg}$ group, $35.6 \%$ in the $0.7 \mathrm{mg} / \mathrm{kg}$ group, $36.4 \%$ in the $0.8 \mathrm{mg} / \mathrm{kg}$ group, and $25 \%(14 / 56)$ in patients who received $0.9 \mathrm{mg} / \mathrm{kg}$ tPA. Our study showed a higher ENI rate than that reported by Felberg et al (22\%). ${ }^{14}$ However, this difference may be because Felberg et al study included only patients with middle cerebral artery occlusion. In our study, the ENI rate was not significantly different among

Table 4 Prognostic factors for unfavorable outcome at 6 months

\begin{tabular}{|c|c|c|c|c|c|}
\hline Variables & Patients $(\mathrm{N}=260)$ & OR $(95 \% \mathrm{Cl})^{a}$ & $P$-value ${ }^{a}$ & OR $(95 \% \mathrm{CI})^{\mathrm{b}}$ & $P$-value ${ }^{b}$ \\
\hline $\operatorname{Sex}(F)$ & $56 / 110(50.9 \%)$ & $1.39(0.85-2.29)$ & 0.19 & $1.80(0.78-3.83)$ & 0.18 \\
\hline \multicolumn{6}{|l|}{ Dose } \\
\hline $0.6 \mathrm{mg} / \mathrm{kg}$ & $31 / 63$ (49.2\%) & 1 & & 1 & \\
\hline $0.7 \mathrm{mg} / \mathrm{kg}$ & $25 / 57$ (43.9\%) & $1.67(0.80-3.49)$ & 0.17 & $1.50(0.72-4.18)$ & 0.22 \\
\hline $0.8 \mathrm{mg} / \mathrm{kg}$ & $30 / 85$ (35.3\%) & $2.07(0.97-4.4 I)$ & 0.58 & I.68 (0.74-4.39) & 0.19 \\
\hline $0.9 \mathrm{mg} / \mathrm{kg}$ & $34 / 55$ (61.8\%) & $2.97(1.47-5.99)$ & 0.02 & $3.55(0.97-5.15)$ & 0.06 \\
\hline Atrial fibrillation & $43 / 86(50.0 \%)$ & $1.26(0.75-2.11)$ & 0.38 & $0.77(0.28-1.61)$ & 0.38 \\
\hline Diabetes mellitus & $49 / 86(57.0)$ & $1.92(1.14-3.24)$ & 0.14 & $1.97(1.02-3.80)$ & 0.04 \\
\hline Hypertension & $103 / 20 \mid(51.2 \%)$ & $2.60(1.37-4.86)$ & 0.003 & $2.14(0.98-4.67)$ & 0.06 \\
\hline \multicolumn{6}{|l|}{ Stroke severity } \\
\hline NIHSS 6-12 & $34 / 125$ (27.2\%) & I & & 1 & \\
\hline NIHSS I3-20 & $5 \mathrm{I} / 88(58.0)$ & $2.12(0.97-4.62)$ & 0.06 & $1.49(0.72-4.14)$ & 0.22 \\
\hline NIHSS $21-26$ & $35 / 47$ (74.5\%) & $7.81(3.63-16.8)$ & $<0.01$ & $18.9(2.96-17.50)$ & $<0.01$ \\
\hline Smoking & $5 \mathrm{I} / 113(45.1 \%)$ & & & $0.12(0.53-2.47)$ & 0.72 \\
\hline Alcohol & I I/27 (40.7\%) & $0.78(0.35-1.79)$ & 0.552 & $0.50(0.50-4.32)$ & 0.47 \\
\hline Hyperlipidemia & $69 / 142$ (48.6\%) & $1.24(0.76-2.03)$ & 0.39 & $0.38(0.66-2.18)$ & 0.53 \\
\hline \multicolumn{6}{|l|}{ Stroke type } \\
\hline Cardioembolism & $40 / 79$ (50.6\%) & 1 & & 1 & \\
\hline LAA & $45 / 73(61.6 \%)$ & $0.68(0.36-1.28)$ & 0.2 & $0.78(0.30-1.97)$ & 0.60 \\
\hline SMO & $3 / 30(10 \%)$ & $0.43(0.23-0.83)$ & 0.01 & $0.42(0.19-0.91)$ & 0.03 \\
\hline UN & $32 / 78(41.0 \%)$ & $6.26(1.75-22.4)$ & 0.005 & $3.16(0.79-12.5)$ & 0.10 \\
\hline \multicolumn{6}{|l|}{ Age (years) } \\
\hline$\leq 50$ & $7 / 30$ (23.3\%) & 1 & & 1 & \\
\hline $5 I-70$ & $50 / 114$ (43.9\%) & $1.52(0.91-2.56)$ & 0.11 & $0.97(0.72-2.63)$ & 0.32 \\
\hline$>70$ & $63 / 116$ (54.3\%) & 3.91 (1.55-9.82) & 0.004 & $3.06(0.88-8.68)$ & 0.08 \\
\hline
\end{tabular}

Notes: aMultiple logistic regression (univariate analysis); ${ }^{b}$ multiple logistic regression adjusted for age, sex, dose, atrial fibrillation, diabetes mellitus, hypertension, stroke severity, smoking, alcohol, hyperlipidemia, and stroke type.

Abbreviations: Cl, confidence interval; LAA, large artery atherosclerosis; NA, not available; NIHSS, National Institutes of Health Stroke Score; OR, odds ratio; SMO, small vessel occlusion; UN, undetermined. 


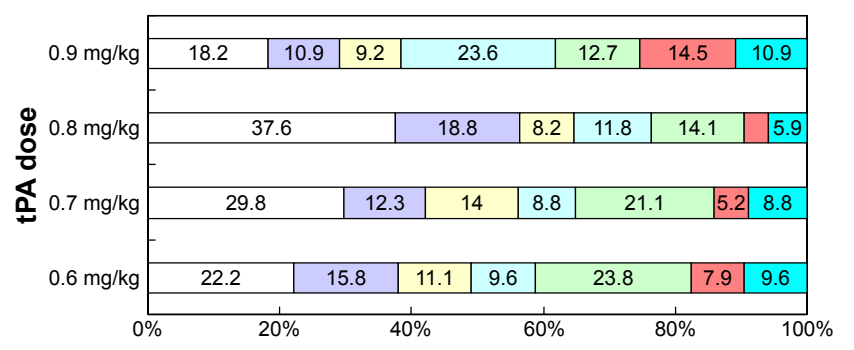

$\square \operatorname{mRS} 0 \square \operatorname{mRS} 1 \square \operatorname{mRS} 2 \square \operatorname{mRS} 3 \square \operatorname{mRS} 4 \square \operatorname{mRS} 5 \square$ mRS 6

Figure 4 Functional outcomes 6 months after stroke, according to modified Rankin Scale score.

Notes: The figure shows the distribution of scores on the modified Rankin Scale at 6 months after stroke. Scores on the modified Rankin Scale range from 0 to 6, with 0 indicating no symptoms, I - without clinical disability, 2 -mild disability, 3 -moderate disability, 4 - moderately severe disability, 5 - severe disability, and 6 - death. Abbreviation: mRS, modified Rankin Scale.

the four groups. Even if we exclude the impact of HT, the ENI rate was slightly lower in the $0.9 \mathrm{mg} / \mathrm{kg}$ group. The cause of the lower ENI rate in the standard-dose group may be related to lower rates of large artery occlusion and lower cardioembolic stroke in the lower-dose group, which lead to a lower blood clot burden in the lower-dose group. In this study, the rates of large artery occlusion and cardioembolic stroke were $52.1 \%(37 / 71)$ in the $0.6 \mathrm{mg} / \mathrm{kg}$ group, $61 \%$ (36/59) in the $0.7 \mathrm{mg} / \mathrm{kg}$ group, $51.1 \%(45 / 88)$ in the $0.8 \mathrm{mg} / \mathrm{kg}$ group, and $78.6 \%(44 / 56)$ in the $0.9 \mathrm{mg} /$ $\mathrm{kg}$ groups. These results show that the ENI rate may be affected by multiple factors, and increasing the tPA dose does not increase the ENI rate. The study by Restrepo et al, found that hypercholesterolemia decreases the likelihood of NI in patients after intra-arterial fibrinolysis and percutaneous mechanical embolectomy. ${ }^{22}$ Their study also found that statin therapy could improve outcome. This result highlights the importance of the treatment of hyperlipidemia. Some studies found low total cholesterol and low-density lipoprotein cholesterol levels to be associated with high sHT rates. ${ }^{23}$ Our results did not find an association of hyperlipidemia with either ENI or HT rate. This difference may be related to the types of patients evaluated in the study of Restrepo et al, that included only patients who received intra-arterial fibrinolysis and percutaneous mechanical embolectomy. It is reasonable to expect that a higher bolus dose may increase the ENI rate. In the ENCHANTED study, the patients received $10 \%$ of total dose (tPA) in the $0.9 \mathrm{mg} / \mathrm{kg}$ group and $15 \%$ of total dose in the $0.6 \mathrm{mg} / \mathrm{kg}$ group as a bolus dose. ${ }^{13} \mathrm{In}$ contrast to the ENCHANTED study, we used $10 \%$ of the total dose as the bolus dose. Our results showed that the ENI rate was not significantly different among the four dose groups. Functional outcome was not significantly different at discharge, but functional outcome at 6 months after stroke onset was poorer in the $0.9 \mathrm{mg} / \mathrm{kg}$ group than in the $0.6 \mathrm{mg} / \mathrm{kg}$ group. After multiple variable analyses, diabetes mellitus, stroke severity (NIHSS $>12$ ), and stroke type (cardioembolism and large artery atherosclerosis) were associated with poor 6-month outcome. Our results echo the findings of Chao et al, who reported that lower doses of tPA had lower HT rates and better outcome. ${ }^{7}$ Previous studies that compared the functional outcome between the low dose and standard dose showed the standard dose to be better than the low dose or found no difference between the low and standard doses. ${ }^{10,12,21}$ In the present study, the ENI rate and NI rate increased as the dose increased from 0.6 to 0.8 $\mathrm{mg} / \mathrm{kg}$ and declined at $0.9 \mathrm{mg} / \mathrm{kg}$. The HT, END, and ND rates mildly increased at doses from 0.6 to $0.8 \mathrm{mg} / \mathrm{kg}$ and sharply increased at dose $0.9 \mathrm{mg} / \mathrm{kg}$. These results suggest that $0.8 \mathrm{mg} / \mathrm{kg}$ is the optimal dose for Taiwanese patients. However, this hypothesis needs to be confirmed by further large-scale investigations. Our study has several limitations. First, the study was not a randomized study; the selection of tPA dose was decided by a neurologist, and the selection of a dose by a physician may be affected by the patient's condition. The patients who may be considered at higher risk of HT may be given a lower dose. This may lead to an underestimation of the benefits of a lower dose. However, the condition of the patients in each of our groups did not significantly differ. Second, most of our patients who were older than 80 years received $0.6 \mathrm{mg} / \mathrm{kg}$ tPA. Third, this was a single-center study involving a relatively small number of patients; therefore, the present study could not offer definitive evidence of the usefulness of this thrombolytic therapy. Fourth, the bolus dose was different in each group, which may affect both the ENI and the HT rates.

\section{Conclusion}

The HT rate increased as the dose increased. The sHT, ENI and the END rates were not significantly different among the lower-dose and standard-dose groups. Diabetes mellitus, stroke severity (NIHSS >12) and stroke type (cardioembolism and large artery atherosclerosis) were associated with poor outcome at 6 months.

\section{Acknowledgments}

We thank Enago for their contribution to English editing.

\section{Disclosure}

The authors report no conflicts of interest in this work. 


\section{References}

1. Mazya MV, Lees KR, Collas D, et al. IV thrombolysis in very severe and severe ischemic stroke: results from the SITS-ISTR Registry. Neurology. 2015;85(24):2098-2106.

2. Ong CT, Sung SF, Wu CS, et al. Early neurological improvement after intravenous tissue plasminogen activator infusion in patients with ischemic stroke aged 80 years or older. J Chin Med Assoc. 2014;77(4): 179-183.

3. Liao X, Wang Y, Pan Y, et al. Standard-dose intravenous tissue-type plasminogen activator for stroke is better than low doses. Stroke. 2014; 45(8):2354-2358.

4. Hacke W, Kaste M, Bluhmki E, et al; ECASS Investigators. Thrombolysis with alteplase 3 to 4.5 hours after acute ischemic stroke. $N$ Engl J Med. 2008;359(13):1317-1329.

5. Asplund K, Glader EL, Norrving B, Eriksson M; Riks-Stroke Collaboration. Effects of extending the time window of thrombolysis to 4.5 hours observations in the Swedish stroke register (riks-stroke). Stroke. 2011;42(9):2492-2497.

6. Rao NM, Levine SR, Gornbein JA, Saver JL. Defining clinically relevant cerebral hemorrhage after thrombolytic therapy for stroke: analysis of the National Institute of Neurological Disorders and Stroke tissue-type plasminogen activator trials. Stroke. 2014;45(9):2728-2733.

7. Chao AC, Hsu HY, Chung CP, et al. Outcomes of thrombolytic therapy for acute ischemic stroke in Chinese patients: the Taiwan Thrombolytic Therapy for Acute Ischemic Stroke (TTT-AIS) Study. Stroke. 2010; 41(5):885-890.

8. Miyagi T, Koga M, Shiokawa Y, et al. Intravenous alteplase at $0.6 \mathrm{mg} / \mathrm{kg}$ for acute stroke patients with basilar artery occlusion: the stroke acute management with urgent risk factor assessment and improvement (SAMURAI) Recombinant tissue plasminogen activator registry. J Stroke and Cerebrovasc Dis. 2013;22(7):1098-1106.

9. Yamaguchi T, Mori E, Minematsu K, et al. Alteplase at $0.6 \mathrm{mg} / \mathrm{kg}$ for acute ischemic stroke within 3 hours of onset: Japan Alteplase Clinical Trial (J-ACT). Stroke. 2006;37(7):1810-1815.

10. Takayanagi S, Ochi T, Hanakita S, Suzuki Y, Maeda K. The safety and effectiveness of low-dose recombinant tissue plasminogen activator $(0.6 \mathrm{mg} / \mathrm{kg})$ therapy for elderly acute ischemic stroke patients ( $\geq 80$ years old) in the pre-endovascular era. Neurol Med Chir (Tokyo). 2014;54(6): 435-440.

11. Dharmasaroja PA, Pattaraarchachai J. Low versus standard dose of recombinant tissue plasminogen activator in treating East Asian patients with acute ischemic stroke. Neurol India. 2011;59(2):180-184.

12. Anderson CS, Robinson T, Lindley RI, et al; ENCHANTED Investigators and Coordinators. Low-dose versus standard-dose intravenous alteplase in acute ischemic stroke. $N$ Engl J Med. 2016;374(24):2313-2323.
13. Alexandrov AV, Demchuk AM, Felberg RA, et al. High rate of complete recanalization and dramatic clinical recovery during tPA infusion when continuously monitored with 2-MHz transcranial doppler monitoring. Stroke. 2000;31(3):610-614.

14. Felberg RA, Okon NJ, El-Mitwalli A, Burgin WS, Grotta JC, Alexandrov AV. Early dramatic recovery during intravenous tissue plasminogen activator infusion: clinical pattern and outcome in acute middle cerebral artery stroke. Stroke. 2002;33(5):1301-3107.

15. Merino JG, Latour LL, An L, Hsia AW, Kang DW, Warach S. Reperfusion half-life: a novel pharmacodynamic measure of thrombolytic activity. Stroke. 2008;39(7):2148-2150.

16. Chang YJ, Ryu SJ, Chen JR, Hu HH, Yip PK, Chiu TF; Consensus Group of Taiwan Stroke Society. [Guidelines for the general management of patients with acute ischemic stroke]. Acta Neurol Taiwan. 2008; 17(4):275-294. Chinese.

17. Fiorelli M, Bastianello S, von Kummer R, et al. Hemorrhagic transformation within 36 hours of cerebral infarct Relationship with early clinical deterioration and 3-month outcome in the European cooperative acute stroke study I (ECASS I) cohort. Stroke. 1999;30(11):2280-2284.

18. Hacke W, Kaste M, Fieschi C, et al. Randomised double-blind placebocontrolled trial of thrombolytic therapy with intravenous alteplase in acute ischaemic stroke (ECASS II). Second European-Australasian Acute Stroke Study Investigators. Lancet. 1998;352(9136):1245-1251.

19. Mehta RH, Cox M, Smith EE, et al; Get With The Guidelines-Stroke Program. Race/Ethnic differences in the risk of hemorrhagic complications among patients with ischemic stroke receiving thrombolytic therapy. Stroke. 2014;45(8):2263-2269.

20. Demchuk AM, Morgenstern LB, Krieger DW, et al. Serum glucose level and diabetes predict tissue plasminogen activator-related intracerebral hemorrhage in acute ischemic stroke. Stroke. 1999;30:34-39.

21. Kim BJ, Han MK, Park TH, et al. Low-versus standard-dose alteplase for ischemic strokes within 4.5 hours: a comparative effectiveness and safety study. Stroke. 2015;46(9):2541-2548.

22. Restrepo L, Bang OY, Ovbiagele B, et al. Impact of hyperlipidemia and statins on ischemic stroke outcomes after intra-arterial fibrinolysis and percutaneous mechanical embolectomy. Cerebrovasc Dis. 2009; 28(4):384-390.

23. Bang OY, Saver JL, Liebeskind DS, et al. Cholesterol level and symptomatic hemorrhagic transformation after ischemic stroke thrombolysis. Neurology. 2007;68(10):737-742.
Drug Design, Development and Therapy

\section{Publish your work in this journal}

Drug Design, Development and Therapy is an international, peerreviewed open-access journal that spans the spectrum of drug design and development through to clinical applications. Clinical outcomes, patient safety, and programs for the development and effective, safe, and sustained use of medicines are the features of the journal, which

\section{Dovepress}

has also been accepted for indexing on PubMed Central. The manuscript management system is completely online and includes a very quick and fair peer-review system, which is all easy to use. Visit http://www.dovepress.com/testimonials.php to read real quotes from published authors. 